\title{
A Research Project about Communism in Romanian Countryside: Ploughmen's Front Propaganda (1944-1953)
}

\author{
Sorin Radu \\ Associate Professor Ph.D., \\ Faculty of Social and Human Science, \\ "Lucian Blaga" University of Sibiu, Romania \\ sorin.radu@ulbsibiu.ro
}

\section{Doi:10.5901/ajis.2013.v2n8p543}

\begin{abstract}
The Ploughmen Front represented the strongest and the oldest "comrade" of the Communist Party from Romania, with a major role in the countryside communization. In general, the studies dedicated to Romania communization focused on institutionalization of the regime, liquidation of democratic order, repression, anticommunist resistance and less on the transformations undergone by the Romanian countryside. The only important issue was the agriculture collectivization. Our project takes into consideration a new approach, which is the research of the way communism became popular in the rural areas, which meant $80 \%$ of the Romanian population, how the popularity of the historical parties was dislocated, especially the National Peasant Party, in these areas. The issue is extremely complex and that is why our intercession will focus on a case study: the role of procommunist propaganda organized by the Ploughmen's Front, the main "comrade" of the communists in communization of the rural area between 1944 and 1953.
\end{abstract}

\section{Problems}

The topic that we are proposing comes, in our opinion, to fill in a period from the Romanian history that remained not enough explained: the process of communization and the role played by the "comrade" of the Communist Party. The Ploughmen's Front represented the strongest and the oldest "comrade" of the Communist Party from Romania, with a major role in the countryside communization. In general, the studies dedicated to Romania communization focused on institutionalization of the regime, liquidation of democratic order, repression, anticommunist resistance and less on the transformations undergone by the Romanian countryside. The only important issue was the agriculture collectivization. Our project takes into consideration a new approach, which is the research of the way the communism became popular in the rural areas, which meant $80 \%$ of the Romanian population, how the popularity of the historical parties was dislocated, especially the National Peasant Party, in these areas. The issue is extremely complex and that is why our intercession will focus on a case study: the role of procommunist propaganda organized by the Ploughmen's Front, the main "comrade" of the communists in communization of the rural area between 1944 and 1953.

\section{What was the Ploughmen's Front Organization?}

Since 1989, there have been very few writings about the activity of the Ploughmen's Front, a post-war political formation with a fairly long existence, but with a short effective political role. The specialized literature offers few approaches to this matter (Ciobanu, Georgescu \& Radu, 2011, 2012; Radu, Ciobanu, 2011; Ciobanu, Radu \& Georgescu, 2012; Radu, 2012; Georgescu \& Radu, 2009; Costea, 2000; Moisa, 2005), advancing only a few tangential references to works of general analysis of the immediate post-war period from a political and economic perspective (Onişoru, 1996; Onişoru, 1998; Târău, 2005; Zainea 2004).

Ever since its establishment (1933), the Ploughmen's Front was a political organization of the most obedient to the Communist Party in Romania, this fact being prominent in the post-war period. Led by Dr. Petru Groza (Bîtfoi, 2004), the Ploughmen's Front was an artificially developed post-war organization, with the specific purpose of countering the influence of the National Peasant Party in rural areas, as well as to mediate the Communist influence among the peasants. From August 23 1944 to its "self-dissolution" in March 1953, its actions were thoroughly supervised by the Communist Party of Romania. One of their first initiatives was to join the National Democratic Front (October 1944), at which point the purpose of this formation was quite clearly stated: "The Ploughmen's Front has the great mission to 
organize the immense energies of the country's huge agricultural sector" (Ardeleanu, Arimia \& Muşat, 1984, 186-188). Officially, the Communist Party tried to stress the independence in action of the Ploughmen's Front due to the lack of adherence of Communist ideas among the peasants, uncovering the relation between the Communists and the Ploughmen's Front being assessed as "a tact mistake that would turn against us" (CNHAB. CC of CPR Fund Chancellery, file 256/1945, 4).

The official documents of the Ploughmen's Front (NARHCD, PS Fund, file 1/1944, 1-5) defined this massorganisation as a "fighting party of the working ploughmen, born from the land-related struggles of the poor ploughmen, from the fight against the exploiting landlords and bankers and their governments". In a purely propagandistic manner, it stated "the tight alliance with the urban working class". The task of the Ploughmen's Front was to organise and mobilise the ploughmen for the improvement of their material and cultural status. In order to achieve this, the Ploughmen's Front was supposed: "a. to intensify the fight against the reaction in the rural area until its complete exhaustion; $b$. to strengthen and deepen the collaboration with the urban working class and its Romanian Communist Party for the preservation, consolidation and development of democracy". The organisational structure of this political formation was the following: the General Congress, the Central Committee, the Joint-communal and County Committees. On a county level, the organisational structure included the County Office, made up of the president of the county organisation, the vicepresidents, the secretary, the person in charge of the organisational department, the person in charge of the educational, press and propaganda department, the person in charge of women's organisation work, the person in charge of the county committee of the young ploughmen, the person in charge of the administrative-financial department, the person in charge of the economical department. The organisational department was the most important. Its general tasks were: to communicate the political direction and tasks of the county committee to the rural ploughmen, who represented the party's foundation, to always know the political and organisational status of the party within the county, to keep a track on the leading cadres starting with the county leaders, members of the county, joint-communal and communal committees, to supervise and direct their ideological evolution, moral behaviour as well as their mode of fulfilling the party tasks. The educational, press and propaganda department was the second most important. Its general tasks were: to continuously elevate the political and cultural level of the members of the county committee and of all the members of the Ploughmen's Front, to contribute to the creating and consolidating the awareness of the peasants within the county regarding their tight relationship with the working class and the Romanian Communist Party, to promote good relations between the Romanian ploughmen and those of other nationalities, to strengthen the alliance with the peoples from the surrounding democrat countries, and especially from the U.S.S.R. and with all the peoples fighting for peace, liberty and the extinction of the last fascist remains, to demonstrate to the working ploughmen that "their worst enemy is rebellion, the imperialist war-provoking trusts, the rebelled expropriated landlords, their subordinates from the villages - the kulaks, all of them, members of the historical parties of Maniu and Brătianu, the enemies of the working ploughmen". In order to complete these tasks, the educational department had to: organise libraries at the county headquarters of the Ploughmen's Front, at the joint communal headquarters, at the community centres, at the commune counselling office comprising books, brochures and newspapers edited by the Ploughmen's Front, the Romanian Communist Party, the Russian Book etc., to organise the rational distribution of the propaganda materials edited by the Central Committee and to control the use of these materials through the organisational apparatus, to explain to the county instructors the important topics of the simple propaganda, the main political events, the main laws voted in the Parliament in favour of the ploughmen, to supervise the political direction of the local newspaper of the Ploughmen's Front, improving its form and content, to keep a record of the theatre teams, the national traditional dances teams, the existent choirs, and coordinate their efforts, implementing a "new progressive content with a repertoire designed to serve the party's political line", to produce local propaganda materials such as posters, slogans, picture placards etc., to organise political meetings from the propagandistic point of view.

The political weight of the Front increased significantly after Dr. Petru Groza has formed the government (6 March 1945) when, with the full logistical support from the State, it became a magnet for peasants. Credible documentary sources estimate that the Ploughmen's Front had approximately 1.5 million members in 1948-1949. After the fraudulent adjudication of the parliamentary elections by the Communists in November 1946, the position of the Communist Party of Romania towards the "comrades" changed. Thus, the attitude of the Ploughmen's Front became much more intransigent, allowing absolutely no "weakness" - a term used by the Communists to designate the deviation of certain elements of the Ploughmen's Front from the strategy they had imposed. In this context, there also appears the "reorganization" that started in 1947, which represented the first step of a process that would eventually lead to the "auto-dissolution" of the Ploughmen's Front in 1953, in fact a fusion with the Romanian Working Party (Georgescu \& Radu, 2009; Jurca, 1994, 364-383). 
In 1949/1950 - 1953 the Ploughmen's Front had organizations in all the villages and communes of Romania and its main task was to spread the ideas of the Communist party among peasants, to translate them the party thesis imposed by the communists, especially those regarding the socialist transformation, the importance of the party in the peasant life and modernization of the village, etc. In order to do this they needed to train some "cultural tutors", "party men" to spread the communist ideas into the peasants' homes. They also needed to organize the propaganda, to build a speech at the peasants understanding level who were mostly illiterate, profoundly religious and extremely reticent regarding the communist thesis, the "proletariat dictatorship", "popular democracy" or "agriculture collectivization".

\section{The Organisation and Importance of the Political Propaganda of the Ploughmen's Front}

On the installation of the first pro-Soviet government led by the Ploughmen's Front's leader, dr. Petru Groza, the Communist propaganda blossomed, as, from then on, apart from the private propagandistic apparatus, the main means and state institutions dominated by the Communist power were fully involved. Under the mask of a generous, but fictional social offer, expressed through the phrase "to build the socialist society", the Communists and their "comrades" conquered the political power in Romania by two means: repression and persuasion. The latter, making use of a large apparatus of propagandists and agitators, attacked the minds and souls of Romanians in the attempt to transform them into obedient slaves, ready to accept the Communist laws, if not gladly, at least as passive and indifferent accomplices, as well as active people, faithful to the new regime.

The Communist propaganda and agitation, whether we refer to the Communist Party or its satellite political organisations (among them, the Ploughmen's Front being the most important), which contributed to the Communist propaganda efforts, paid great attention to the ideological training of its own cadres, its own activists, who, besides strengthening the feeling of belonging to an elite, ensured loyalty towards the party by protecting it against the external "evil influences". In this regard, the Communist propaganda and agitation had a general offensive character, although it did not neglect the protective defensive elements. All of these defensive elements were grouped under the larger frame of censorship (Gabanyi, 2001, 27-40). Press censorship, overwhelming during that period, was primarily aimed at the severe limitation and ultimate elimination of any information contradictory to the regime's interest (Deletant, 2001, 75). These actions were followed by an intense process of political purification within the state's structures, initiated after the installation of the pro-Soviet government led by Dr. Petru Groza (6 March 1945).

According to the Organisational Statute approved during the Central Committee meeting on the 26-27 November 1944, and also to the publications designed to describe the political aim of the Ploughmen's Front (Frontul Plugarilor, $1944,4,5)$, the leaders of this mass political group highlighted the organisation of the propagandistic undertake, its dynamics and architecture, considering the socio-professional categories of those whom it would address.

Propaganda was considered the most important instrument for shaping the political conscience of any citizen willing to fight for his or her political dream. Starting from the totalitarian ideological precept, according to which "propaganda is the essential issue in creating the new man", the Front's leaders designed and imposed the evolution of propaganda in five major sections: political propaganda, cultural propaganda, information and press, professional circles and, "crowning them all" - the cadre school. The political propaganda section had to elaborate political propaganda materials (slogans, posters etc.), and keep record of the propaganda instructors and their field activity. This section "had to pay attention to the activities of the other sections as well, offering them not only the materials, but also the line to be followed". The cultural propaganda section organised cultural manifestations of the Ploughmen's Front, in a manner that would "always conceal the political direction of the Ploughmen's Front". The information and press section was responsible for editing and distributing the periodical publications of the Ploughmen's Front, written in a journalist style which the peasants could understand, most of them being semi-illiterate (Ce trebuie să ştie un luptător al Frontului Plugarilor, 1945, 14-30). The professional circles section aimed to integrate intellectuals in the Ploughmen's Front, in this context demonstrating this organisation's attitude towards intellectuals in general, as they were regarded "with distrust and even hostility". The section's mission was more difficult, as it was based on the Communist ideological and propagandistic cliché according to which "in the past and in the present, most intellectuals represented the people's enemies". However, there was a distinction between the democratic intellectuals whom the organisation needed, and the reactionary intellectuals, alien to the ploughmen's interests. Underneath this stereotype formula and beyond any ideological differentiation, there was a latent and acute need for specialists, who were supposed to be politically aligned in order to implement the reformation programme for the peasants. At the same time, the increased adhesion of intellectuals and specialists would consolidate the Front's credibility on a rural community level, where there was need for greater legitimacy: "the professional circles of intellectuals and specialists (agronomists and agronomical engineers, 
doctors and veterinaries, silviculturists, educators, teachers, priests), all of them have a salutary and decisive role within the Ploughmen's Front. They have to help the organisation with their specialties" (Primul Congres general al Frontului Plugarilor, 1945, 191-193). Even the Front's organisational statute paid great attention to intellectuals, allowing a third of its members to be "illuminated individuals" (Frontul Plugarilor, 1944, 6).

The fifth component of the Ploughmen's Front propaganda - which we will further focus upon - was the cadre school, highly appreciated due to its purpose of instructing party activists, party clerks, (in one word: the party cadres); they were faithful to the new Communist regime, zealous, fully indoctrinated, and were supposed to transmit the Ploughmen's Front's and, implicitly, the Romanian Communist Party's line to the rural world.

\section{Summary of the Research Project}

From our point of view, the institutionalization of the communist regime in Romania, the imposing of the Russian society model cannot be understood without a detailed analysis of the way in which the ideas about the "new world" and "the new man" entered in the Romanian rural areas, among the peasants who were mainly reticent to changing. It is fundamental to understand how the peasants regarded the communism, what were the convincing methods, the reaction to the propagandistic clichés and the perception of the different "changes" imposed by the new masters of Romania. Our research tries to answer at least to a part of these questions. This research project has started this year and it will finish in 2015, the author of this article being the coordinator of the research team. This work was supported by The National Research Council from Romania (CNCS).

The difficulty of such an intercession is determined by the depth and the greatness of the phenomena of communizing the rural areas, by the great amount of informing sources, both those from the archive as those from the oral history. That is why our main focus will be that of reducing the research to valuating the archive sources from the most important backgrounds, those in Bucharest, and valuating the four representative county archives (Dolj, Hunedoara, Timiș, lași). Regarding the oral investigations we will take into consideration some case studies that will be described below.

\section{Concrete objectives of the project:}

1. to assess the Romanian and foreign historiography regarding the propaganda of communizing the Romanian countryside and its compared analysis in the context of the Russian concentration camp, insisting on the role of the "comrade" of the communists;

2. to analyze the structure and organization of the propaganda of the Ploughmen's Front in the countryside; tools of propaganda; the analysis of the propagandistic speech; topics and clichés of the propaganda; „education” I „training" of the political propagandists; the organizing and the activity of the staff schools of the Ploughmen's Front; the profile of the ploughman activist ; „party work” of the propagandists and its efficiency;

3. Soviet Union perspective on the role of Ploughmen Organization propaganda; assessing the Russian historiography and archive regarding the activity of the Ploughmen's Front;

4. framing the propaganda of the "comrade" - Ploughmen's Front - in the context of setting up the communism in the Eastern Europe (comparisons with similar political organizations from the Russian concentration camps);

Elements of originality and innovation: none of the objectives mentioned above have been approached in the Romanian or foreign historiography. The novelty of this intercession is also doubled by the intention of valuating some unprecedented archive background (Central Historical and National Archives, National Council Archives for Security Archives Studying as well as the county archives), of valuating the party mass media, of the information acquired through field investigations (oral history) as well as the partial valuation of the Russian archive. Our project has as a fundamental objective the understanding of Romania communizing by researching the way the communist ideas penetrated among the peasants, their impact on the countryside through a case study: the propagandistic activity of the Ploughmen Front the most important organization controlled by the communists with activity mainly in the rural areas.

\section{Methodology}

a. Documentation internships in libraries from Sibiu, laşi, Bucharest, Regensburg (The Research Centre for Eastern and South Eastern Europe), München (Institut für deutsche Kultur und Geschichte Südosteuropas), 
Vienna (Austrian National Library), Moscow (Historical Public Library and State Library of Russia). Direct access to electronic data (www.sciencedirect.com, www.ebrary.com, www.oxfordjournals.org, www.journals.cambridge.org etc.);

b. Archive research represents the background of our project. We are planning to research mainly in the following archive funds: a) Central National Historical Archives Bucharest: The Archive of the Central Committee of the Communist Party from Romania, the Ploughmen's Front Fund - the most important archive fund for our research; The fund of the Central Committee of the Communist Party in Romania - Secretariat, Internal Documents, Organizational Department, Propagandistic and Agitation Department, Popular Democratic Front, General Inspectorate of Gendarmerie, General Department of Militia; b). The Archive of National Council for the Study of Archives of Securitate - Documentary Fund, Informative Fund; c). The archive funds of four representative county organizations of Ploughmen's Front: Hunedoara, Timiş, Iaşi, Dolj;

c. Press research - important means of transmission for propaganda messages; we are taking into consideration the ploughmen newspapers: „Horia” (1945); „Frontul Plugarilor” (1945-1952) and also the communist official newspaper "Scânteia” (1944-1953);

d. critical analysis of propaganda materials published by the Ploughmen's Front in 1944-1953: booklets, handouts, books, other propaganda materials;

e. field inquiry, oral history. Approaching the subject from the perspective of oral history we try to detect the ways through which the events and phenomena of recent Romanian history have reflected and influenced the life of some communities; the emphasis and highlighting the mentalities and attitudes in some rural communities in the early years of communism. The research will imply on the one hand a historical dimension to show the way the propaganda of the Ploughmen's Front has changed in time, depending on the important social and politic events of the certain period and, on the other hand, a synchronic dimension aiming a comparative analysis between communities. From the point of work methodology on oral history research we are planning to use oral inquiry, based on a semi-structured interview. This will be applied on a representative group, with subjects chosen depending on age, sex, studies, but the most important selection criteria will be the existence of memories regarding the research subject. The dialogue with the selected persons will take place on the base of a prior drafted interview. The interviews will be recorded on digital audio format, then transcribed and used connected to other sources (archive documents, press etc.) to get scientific studies. Locations where the oral history research will take place: Transylvania: Băcia and Veţel (Hunedoara County); Oltenia: Bârca (Dolj County); Cilieni (Olt County); Moldova: Bălţaţi, Prisăcani (Iaşi County).

f. archive research in Moscow for understanding the attitude of the Soviet Union over the Ploughmen's Front and its contribution at Romania's communization: State Archive of Social-Political History of the Russian Federation (the Archive of the Comintern) - S.A.S.P.H.R.F. and The Archive of External Politic of the Russian Federation. From a thematic point of view, documents kept at S.A.S.P.H.R.F. span over three big fields: a. Documents referring to social and political history in Europe from the XVIIt to $X X^{\text {th }}$ centuries; $b$. Documents regarding the history of Russia and U.S.S.R.; c. Documents related to the history of socialist and communist. Next to general funds which contain not only secondary information regarding Romania, but also punctual, very interesting information, like the debates in the leading forums of the Comintern or of the Communist Party of Russia, S.A.S.P.H.R.F. hosts rich collections with express reference to the Romanian issue. Being grouped mainly in the funds 495 and 496 , those collections contain materials referring to the "Romanian Comissions" from the Comintern and Romanian Communist Party etc. From the Archive of External Politic of the Russian Federation we are interested mainly into the funds referring to the time after the Bolshevik revolution.

\section{The Dissemination of the Results of the Research}

The fundamental aim is both the dissemination of the results of the project in national and international terms (based on the innovation of the project in Romania). In consequence, we want to achieve: a web page of the project in Romanian and English, hosted on the server of the "Lucian Blaga" University of Sibiu; the publication of eight scientific studies, four of them in reviews like Web of Science Arts \& Humanities Citation Index or ERIH - INT 1 and four of them in peer reviewed journals; the organization of an international conference that should gather specialists of the issue - financed with other founds than the ones of the project; the publication of a collective volume at a famous publishing house from abroad that should assure a very good visibility among the researchers; participation at four scientific conferences, two of them international conferences. 


\section{Expected Impact}

The novelty of the intercession and the complexity of the research methodology can bring into light important conclusions that will change some perceptions, clichés regarding the attitude of the Romanian peasants towards the communism. In general, the historiography emphasized the idea that the penetration of the communism in the rural areas was the result of some abusive actions of the communists supported by the Russians. One of the challenges of our project regards the question: how much a part of the Romanian peasantry, that was living in poverty, illiteracy and regress, didn't fall in the trap of communist propaganda displayed also through the Ploughmen's Front and let itself be conquered by the deceiving promises of a better life and of getting out of the poverty, etc. The archive investigations and especially the oral history inquiries that we will develop in some rural communities will confirm us or not such a theory. It also must be emphasized the importance of valuating the Russian archives in order to understand the communist impact in the rural areas, which were extremely rarely used by the Romanian and foreign researchers, mostly due to the difficulty of accessing them and of the Russian language ignorance.

In nowadays society there is a great necessity of understanding the communism, the institutionalization of the communist regimes from Eastern Europe and especially of the way in which this ideology influenced the societies from this area. It is important to understand how the Eastern European societies and particularly the Romanian society, characterized by traditionalism, peasantry way of life and with a profound religious sense, were transformed in a relative short time through a pure social engineering and by applying the Russian model. Our project proposes, through a case study, the understanding of the way in which through the communist propaganda, the Romanian rural areas transformed, accepting the communism. From this perspective, we consider that the impact of our intercession within the academic, national, Eastern European and international communities, will be great.

The dissemination ways of this research results (scientific studies, conferences attendance, the volumes that will be published etc) will allow a very good circulation of the ideas and conclusions that will be the results of this research. Posting this website on "Lucian Blaga" University of Sibiu server will provide a very good visibility among the students and researchers from the county and abroad.

\section{Acknowledgement}

This work was supported by a grant of the Romanian National Authority for Scientific Research, CNCS - UEFISCDI, project number PN-II-RU-TE-2012-3-0334.

\section{References}

CNHAB. CC of CPR Fund - Chancellery - The Central National Historical Archives in Bucharest. The Central Committee of the Communist Party of Romania Fund - Chancellery.

NARHCD, PS Fund - The National Archives of Romania. The Hunedoara County Department, The Ploughmen's Front Fund. The Hunedoara County Committee.

Ardeleanu, I., Arimia, V., Muşat, M., (Editors). (1984). August 23rd 1944. Documents 1939-1943, vol. I (p. 186-188), Bucharest: Political Publishing House.

Bîtfoi, D.L. (2004), Petru Groza, ultimul Burghez. O biografie [Petru Groza, the Last Bourgeois. Biography], Bucharest: Compania Publishing House.

Ce trebuie să ştie un luptător al Frontului Plugarilor (1945) [What Must a Fighter of Ploughmen's Front Know], 2nd edition, Bucharest.

Ciobanu, V., Radu, S. \& Georgescu, N., (Editors). (2011, 2012). Frontul Plugarilor. Documente [Ploughmen's Front. Documents], vol I (1944-1947), vol II (1948-1951), Bucharest: National Institute for the Study of Totalitarianism Publishing House - Romanian Academy.

Ciobanu, V., Sorin Radu \& Nicolae Georgescu (2012). Frontul Plugarilor [The Ploughmen's Front]. In Enciclopedia comunismului românesc, vol. II, (p. 91-99), Bucharest: National Institute for the Study of Totalitarianism Publishing House - Romanian Academy.

Costea, S. (2000). Aspecte ale instaurării puterii comuniste în România. Rolul Frontului Plugarilor în judeţul Mureş (1944-1947 [Aspects of the Establishment of Communist Power in Romania. The Role of the Ploughmen's Front in the Mureş County (1944-1947)]. Apulum, 37 (2), 275-282.

Deletant, D. (2001). Teroarea comunistă în România. Gheorghe Gheorghiu-Dej şi statul poliţienesc 1948-1965 [The Communist Terror in Romania. Gheorghe Gheorghiu-Dej and the Police State 1948-1965]. Iaşi: Polirom Publishing House.

Frontul Plugarilor. Statutul de organizare aprobat în şedinţa Comitetului Central al Frontului Plugarilor din 26/27 noiembrie 1944 (1944) [The Ploughmen's Front. The Organisational Statute Approved in the Central Committee Meeting in 26 - 27 November 1944]. 
Bucharest.

Gabanyi, A.U. (2001). Literatură şi politică în România după 1945 [Literature and Politics in Romania after 1945]. Bucharest: Romanian Culturales Foundation Publishing House.

Georgescu, N. \& Radu, S. (2009). Refacerea politică şi extinderea organizatorică a Frontului Plugarilor în anii 1944-1945 [The Political Restoration and Organisational Expansion of the Ploughmen's Front in 1944-1945]. Studia Universitatis Petru Maior. Historia, 9, 198-214.

Georgescu, N., Radu, S. (2009). Autodizolvarea Frontului Plugarilor (1953) [The Self-Dissolution of the Ploughmen's Front]. Apulum, XLVI, 211-231.

Jurca, N. (1994). Istoria social-democraţiei din România [The History of Social-Democracy in Romania]. Bucharest: Scientific Publishing House.

Moisa, G. (2005). Tovarăşii de drum ai comuniştilor în Regional Crişana- Maramureş 1944-1953 [The Fellow-Travellers of The Communists within the Crişana-Maramureş Region 1944-1953]. Anuarul Institutului de Istorie George Bariţ, XLIV, 331-347.

Onişoru, G. (1996). Alianţe şi confruntări între partidele politice 1944-1947 [Alliances and Confrontations between Political Parties], Bucharest: Fundaţia Academia Civică.

Onişoru, G. (1998). România în anii 1944-1948. Transformări economice şi realităţi sociale [Romania between 1944 and 1948. Economical Transformations and Social Realities], Bucharest: Fundaţia Academia Civică.

Primul Congres general al Frontului Plugarilor (1945) [The First General Congress of the Ploughmen's Front]. Bucharest.

Radu, S. \& Ciobanu, V. (2011). Frontul Plugarilor şi minorităţile naţionale [The Ploughmen's Front and the National Minorities]. In Ciobanu, V., Solomon, F. \& Radu, S. (Editors), Partide politice şi minorităţi naţionale din România în secolul XX [Political Parties and National Minorities in Romania XXth Century], vol. VI (p. 15-46), Cluj-Napoca: Kriterion Publishing House, Romanian Institute for Research on National Minorities Publishing House.

Radu, S. (2012). „Tovarăşi de drum”: Frontul Plugarilor şi Partidul Comunist în anii 1944-1947. Revista istorică, XXIII (1-2), 107-138;

Târău, Ț. (2005). Alegeri fără opţiune. Primele scrutinuri parlamentare din Centrul şi Estul Europei după cel de-al Doilea Război Mondial [Choices without Option. The First Parliamentary Polls in Central and Eastern Europe after World War II], Cluj-Napoca: Eikon ublishing House.

Zainea, I. (editor). (2004). Democraţie Occidentală şi Democraţie populară. Evoluţia spectrului politic în Nord Vestul României 19441950 [Western Democracy and the People's Democracy. The Evolution of the Political Spectrum in North-Western Romania 1944-1950], Oradea: Oradea Publishing House. 